\title{
Loranthus europaeus (Loranthaceae) in Ukraine: an overview of distribution patterns and hosts
}

\author{
Yuliya A. KRASYLENKO ${ }^{1,2}$, Ruslan Yu. GLEB ${ }^{3,4}$, Olena D. VOLUTSA ${ }^{5,6}$ \\ ${ }^{1}$ Centre of the Region Haná for Biotechnological and Agricultural Research, Palacký University Olomouc \\ 27 Šlechtitelů Str., Olomouc 783 71, Czech Republic \\ ${ }^{2}$ Institute of Food Biotechnology and Genomics, National Academy of Sciences of Ukraine \\ 2a Osipovskogo Str., Kyiv 04123, Ukraine \\ ${ }^{3}$ Carpathian Biosphere Reserve \\ 77 Krasne Pleso Str., Rakhiv 90600, Ukraine \\ ${ }^{4}$ M.M. Gryshko National Botanic Garden \\ 1 Timiryazevska Str., Kyiv 01014, Ukraine \\ ${ }^{5}$ Yuriy Fedkovych Chernivtsi National University, Institute of Biology, Chemistry and Biological Resources \\ 11 Fedkovych Str., Chernivtsi 58022, Ukraine \\ ${ }^{6}$ Khotyns'ky National Nature Park \\ 69 Olimpiyska Str., Khotyn 60000, Chernivtsi Region, Ukraine \\ y.krasylenko@gmail.com; gleb.ruslan@gmail.com; o.volutsa@chnu.edu.ua
}

Krasylenko Yu.A., Gleb R.Yu., Volutsa O.D. 2019. Loranthus europaeus (Loranthaceae) in Ukraine: an overview of distribution patterns and hosts. Ukrainian Botanical Journal, 76(5): 406-417.

Abstract: Updated information on geographic distribution patterns and hosts of Loranthus europaeus in Ukraine is presented as a list of known localities and a schematic map based on data of field observations, herbarium collections, and literature sources. The field study areas with eight localities directly surveyed by the authors included: Chernivtsi Region (Hertsayivs'ky and Kelmenets'ky districts), Zakarpattia (Transcarpathian) Region (Rakhivs'kyi District) and Khmelnyts'kyi Region (Kamianets-Podils'ky District) of Ukraine. In Ukraine L. europaeus has been recorded since the $19^{\text {th }}$ century. In total, it was reported from ca. 30 localities in Ukraine, mostly in the southwestern regions of the country at the northeastern limits of the Eastern European part of its range. The records from Kyiv Region and Crimea remain questionable. Within its range in Ukraine, L. europaeus parasitizes Quercus species as its primary hosts. In our opinion, this mistletoe species is not expected to become a noxious pest causing considerable damage for the Ukrainian forests, unlike the European mistletoe, Viscum album. Moreover, L. europaeus is recommended for special protection in Khmelnyts'kyi Region and is included in the list of regionally rare plants of administrative units of Ukraine.

Keywords: distribution, hosts, Loranthus, mistletoe, Quercus, range, stem hemiparasite, Ukraine

Submitted 11 March 2019. Published 31 October 2019

Красиленко Ю.А. ${ }^{1,2}$, Глеб Р.Ю.,3,4, Волуца О.Д., ${ }^{5,6}$ 2019. Loranthus europaeus (Loranthaceae) в Україні: огляд особливостей поширення та рослин-господарів. Ukrainian Botanical Journal, 76(5): 406-417.

${ }^{1}$ Центр біотехнологічних та сільськогосподарських досліджень регіону Хан'я при Університеті Палацького в Оломоуці

вул. Шлехтітелу 27, Оломоуц 783 71, Чеська Республіка

${ }^{2}$ ДУ "Інститут харчової біотехнології та геноміки Національної академії наук України"

вул. Осиповського 2а, Київ 04123, Україна

${ }^{3}$ Карпатський біосферний заповідник

вул. Красне Плесо 77, Рахів 90600, Україна

${ }^{4}$ Національний ботанічний сад імені М.М. Гришка НАН України

вул. Тімірязєвська 1, Київ 01014, Україна

5Чернівецький національний університет імені Юрія Федьковича, Інститут біології, хімії та біоресурсів, кафедра ботаніки, лісового і садово-паркового господарства

вул. Федьковича 11, Чернівці 58022, Україна

${ }^{6}$ Хотинський національний природний парк

вул. Олімпійська 69, Хотин 60000, Чернівецька обл., Україна

Реферат. У статті наведено оновлені відомості щодо поширення та рослин-господарів рідкісного стеблового напівпаразита дубової омели європейської (Loranthus europaeus) в Україні у вигляді переліку локалітетів та схематичної мапи, складеної на основі польових спостережень, опрацювання гербарних зборів та літературних джерел. Авторами було безпосередньо досліджено близько восьми локалітетів у Чернігівській (Герцаївський та Кельменецький райони), Закарпатській (Рахівський район) та Хмельницькій (Кам'янецьПодільський район) областях. Перші знахідки L. europaeus в Україні відомі з 19 ст. Загалом, цей вид знайдено у близько 30 локалітетах переважно у південно-західний частині України, де він перебуває на північно-східній межі східноєвропейського ареалу. Знахідки у Київський області та Криму потребують підтвердження. Головними господарями L. europaeus в Україні є різні види дубів (Quercus spp.). Цей вид омели, на відміну від омели білої (Viscum album), не завдає суттєвої шкоди лісам України і наразі вона не вважається фітокарантинним видом. Більш того, L. europaeus рекомендовано охороняти на регіональному рівні у Хмельницькій області.

Ключові слова: ареал, омела, поширення, рослини-господарі, стеблові напівпаразити, Україна, Loranthus, Quercus

(C) 2019 Yu.A. Krasylenko, R. Gleb, O. Volutsa. Published by the M.G. Kholodny Institute of Botany, NAS of Ukraine. This is an open access article under the terms of the Creative Commons Attribution License (http://creativecommons.org/licenses/by/4.0/), which permits use, distribution, and reproduction in any medium, provided the original work is properly cited 


\section{Introduction}

Mistletoes, which is an English vernacular name for many species of obligate hemiparasitic plants belonging to several currently recognized genera (e.g., Viscum L., Arceuthobium M. Bieb., Tupeia Cham. \& Schltdl., Phoradendron Nutt., Strutanthus Mart., Loranthus Jacq., etc.) and even families of Santalales (e.g., Viscaceae, Santalaceae, Loranthaceae, etc.), are aerial hemiparasites of woody plants distributed widely from tropical to boreal physiographic zones (Beylin, 1986; Aukema, 2003; Mathiasen et al., 2008; Nickrent, 2010; Kuijt, 2015). Their role in forests and other habitats/ ecosystems is considered to be ambivalent, or even contradictory. First, mistletoe fruits, due to their persistence in cold seasons in temperate regions, are usually consumed by birds and other animals. At the same time, mistletoes compromise trees' water balance and photosynthetic activity as pests by pirating water due to the haustorial connection of their endophytes to the host vascular system (Watson, 2001). Ornithochory favors an aggregated spatial distribution of infected trees (Glatzel, Geils, 2008). The infestation patterns are mostly discrete and distance-dependent (Matula et al., 2015).

The taxonomic circumscription of Loranthus Jacq. (Loranthaceae) considerably changed over time, and it remains problematic even now. Various authors recognized in the genus from ca. 500 or even 600 species (Krüssmann, 1977, and earlier authors) to ten (Nickrent et al., 2010) or just two (Kujit, 2015) species. In earlier literature the genus encompassed most species of mistletoes parasitizing representatives of phylogenetically distant taxa (Krüssmann, 1977). Recently, according to the fundamentally revised phylogenetic classification of Santalales by Nickrent et al. (2010) based on nucleotide sequence data, it is widely accepted that subtribe Loranthinae Engl. includes just two genera: monotypic Cecarria Barlow with the only species C. obtusifolia (Merr.) Barlow inhabiting the Philippines, New Guinea, New Britain, and the Solomon Islands, and Loranthus Jacq. with ca. ten species occurring from Europe to southern China, and Sumatra. This classification is supported by palynomorphological data, since the genus Loranthus from subtribe Loranthinae, clade G, have pollen of Type B (Grímsson et al., 2018). However, Kuijt (2015) recognized only two species of Loranthus. Moreover, phylogenetic analysis of $L$. europaeus mitochondrial genome performed for the studies of the mitochondrial genome evolution places this species in the Santalales as sister to Gaiadendron G. Don (Loranthaceae) (Zervas et al., 2019), though the taxonomic classification of Nickrent et al. (2010) separates Loranthus and Gaiadendron into different clades, and places these two genera in two different tribes, Lorantheae та Gaiadendreae, respectively.

The only European species of this genus, Loranthus europaeus Jacq. (synonyms: L. dioicus Stokes, Hyphear europaeum (Jacq.) Danser; vernacular name: yellow or yellow-berried mistletoe) is a widespread deciduous hemiparasitic plant (Uotila, 2011-onward). Primary hosts of L. europaeus are species of Quercus L. (Fagaceae), such as $Q$. pubescens Willd., Q. cerris L., Q. robur L., Q. petraea (Matt.) Liebl., though it may also occur on Castanea sativa Mill. (Fagaceae) and rarely on Olea europaea L. (Oleaceae) (Krüssmann, 1977; Eliás,1985; Zebec, Idžojt, 2006; Kumbasli et al., 2011; Saraj et al., 2015). It was reported that in Croatia it parasitizes several native and introduced oak species $(Q$. robur, $Q$. petraea, $Q$. cerris, $Q$. pubescens, $Q$. frainetto Ten., Q. rubra L., Q. palustris Münchh.) and Castanea sativa (Fagaceae), and also Carpinus betulus L. (Betulaceae) (Zebec, Idžojt, 2006). In Slovakia $L$. europaeus was also found on $Q$. pubescens, $Q$. cerris, $Q$. petraea, $Q$. robur, $Q$. dalechampii Ten., Q. virgiliana (Ten.) Ten., Q. rubra (Fagaceae), and on Betula pendula Roth (Betulaceae). Some additional hosts were reported, but these records remain unconfirmed: Acer campestre L., Castanea sativa, Carpinus betulus, and Crataegus monogyna Jacq. (Eliás 2002). In Slovenia (Kogelnik, 2002) L. europaeus parasitizes three native species of oak ( $Q$. petraea, $Q$. pubescens and $Q$. robur) and Castanea sativa. The infestation rate (also known in literature as "infection rate") was greatest on $Q$. petraea and lower in $Q$. frainetto; no infestation was detected on $Q$. cerris in Turkey (Kumbasli et al., 2011). In the early publication by von Tübeuf (1923), several resistant non-host species for L. europaeus were mentioned, since the attempts to infect artificially were unsuccessful: Populus balsamifera L., Malus domestica (Suckow) Borkh. (reported as Pyrus malus L.), Prunus padus L., and Laburnum anagyroides Medik. (reported as Cytisus laburnum L.). Furthermore, hyperparasitism (epiparasitism) of Viscum album L. subsp. album on L. europaeus was described as well (Grazi, Urech, 1986). 
Loranthus europaeus is widely distributed in Central and Southeastern Europe, the Eastern Mediterranean region, and also has several isolated populations in Asia Minor (Glatzel et al., 2016). In Ukraine, records of L. europaeus are quite scarce. These issues are addressed in the present article based on our revision of available specimens in the Ukrainian herbaria, relevant literature, and field observations made during 20052019.

\section{Materials and Methods}

\section{Herbaria}

The specimens from the main Ukrainian herbaria: KW (National Herbarium of Ukraine, M.G. Kholodny Institute of Botany, National Academy of Sciences (NAS) of Ukraine, Kyiv), KWHA (M.M. Gryshko National Botanical Garden, NAS of Ukraine, Kyiv), KWHU (O.V. Fomin Botanical Garden of Taras Shevchenko National University of Kyiv, Kyiv), LW (Institute of Ecology of the Carpathians, NAS of Ukraine, Lviv), UU (Uzhhorod National University, Uzhhorod), MSUD (I.I. Mechnykov National University of Odessa, Odessa) and CHER (Yuriy Fedkovych Chernivtsi National University, Chernivtsi) were studied. It has to be noticed that specimens of L. europaeus have not been found in or reported from KWU, LWKS, YALT, ASCN, LBE, SIBS, CSAU, SIMF, PHEO, DSU, ZAU, KRW, KRWI, MELIT, LUM, and LUU.

The following herbaria were visited by the authors of the present article, and all specimens of Loranthus from Ukraine available in these herbaria were physically examined: KW, KWHA, and CHER.

We also received digital images of and/or information on available specimens from some other herbaria; that information was provided by their staff or other colleagues (see Acknowledgments), in particular: KWHU, LW, MSUD, and UU.

In the list of localities below we cite (1) herbarium specimens (the specimens physically studied in herbaria are marked with "!" following the herbarium acronym); (2) digital images of herbarium specimens provided from some herbaria (accompanied by the word "image"); (3) reliable publications (with relevant references given); (4) original observations of the authors of the present article, and (5) personal communications ("pers. comm.") of colleagues.

Herbarium acronyms are given following Index Herbariorum (Thiers, 2008-onward) and, if necessary,
Index Herbariorum Ucrainicum (Shiyan, 2011). Specimens from the herbaria of the neighboring countries (e.g., Poland, Czech Republic, Slovakia) have not been studied. We hope that they will be analyzed in our further studies.

\section{The survey areas}

The field study areas directly surveyed by the authors included: Chernivtsi Region (Hertsayivs'ky and Kelmenets'ky districts), Zakarpattia (Transcarpathian) Region (Rakhivs'kyi district) and Khmelnyts'kyi Region (Kamianets-Podils'ky district) of Ukraine. Ca. 8 localities were attended during route and area surveys.

\section{Mapping}

The distribution range of $L$. europaeus is presented on a map according to the subdivision of Ukraine into administrative regions (in Ukrainian, singular: oblast, область) and districts (rayon, район). Chorological data (herbarium specimens, literature data and original observations) are presented here as a list of localities (alphabetically arranged within administrative units).

\section{Results and Discussion}

Morphological characteristics and biological peculiarities of Loranthus europaeus related to its hemiparasitism, distribution and dispersal

The occurrence of this deciduous mistletoe on host stems and/or branches can be diagnosed from the distance as it forms spherical tufts (clutches) ca. 60-80 $\mathrm{cm}$ in diameter, scattered on the host branches and/or stems (Fig. 1; Fig. 2, A, B, C).

Fusiform malformations are present at sites of the old aerial exophyte (outer part) entry on host terminal branches (Fig. 2, B (arrow), F). Loranthus europaeus is green from early spring to late autumn (Fig. 2, A, B, E, G), then it loses leaves (Fig. 2, C, F) and bears yellow berries in winter (Fig. 2, D, O).

Fragile dark brown aerial shoots of $L$. europaeus have sympodial pseudodichotomous branching, are 1.0-5.0 $\mathrm{cm}$ in diameter near the base, narrowing at younger branches (Fig. 2, E, G) (Morozyuk, 1987; Kubát, 1997).

Flowering in Ukraine occurs in May-August, fruits ripen in November and persist during winter (Morozyuk, 1987). The seeds covered with sticky viscin ("bird glue") (Fig. 2, L, M, N) are dispersed by birds, such as the common blackbird (Turdus merula L.), mistletoe trush (T. viscivorus L.), and jay [Garrulus glandarius (L.)] 


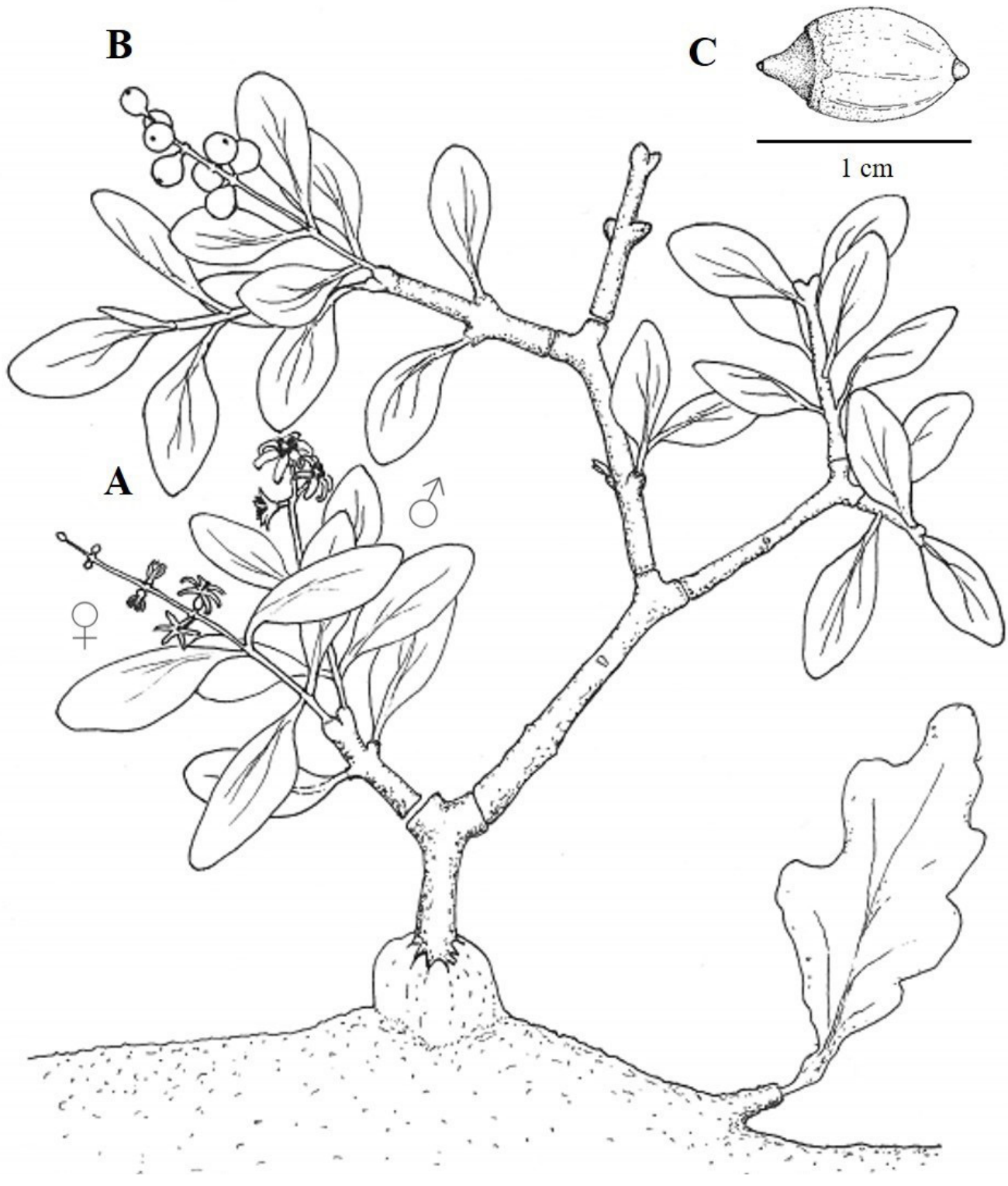

Fig. 1. An exophyte of hemiparasitic Loranthus europaeus on its primary host (Quercus sp.). A: staminate (つ) and pistillate ( $(+)$ flowers; B: fruits; C: seed. Graphical drawings by Kateřina Janošikova. 

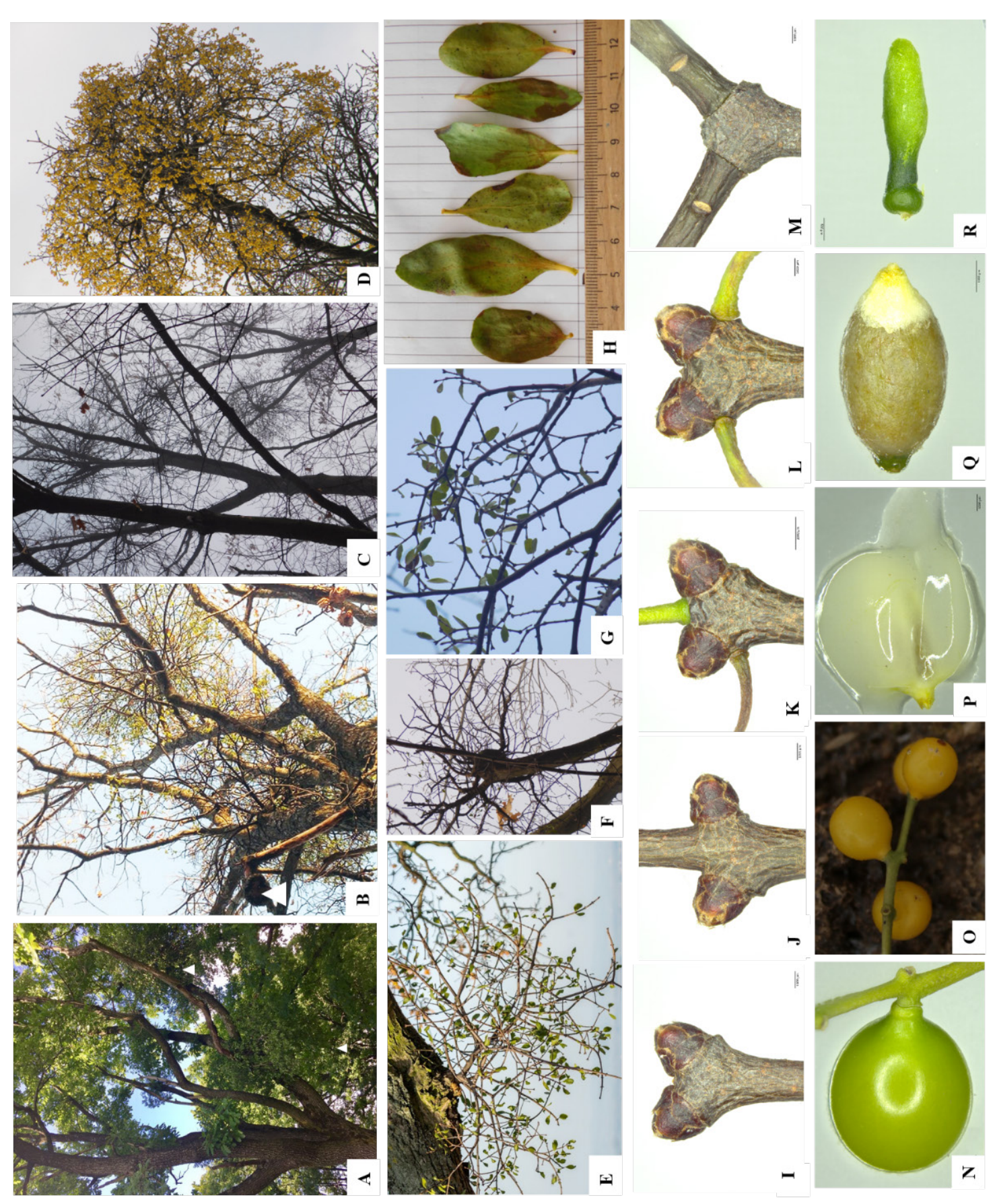

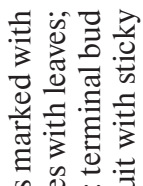

象证

要

政

눙

os

政

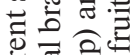

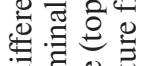

.

OQ

政

응

ร.을

프

今。

可 웜

网

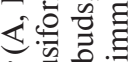

的公

议运

ऽิ ฮु

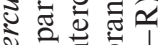

ऽ)

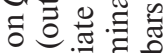

过

造

次

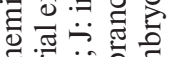

ज्ञ

计

현 즐

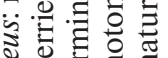

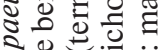

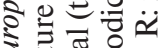

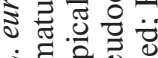

고응

4.

o $\overline{\bar{\sigma}}$

10

o.

×.

政它

tै

跑?

응

응

勿

之.

त

. 


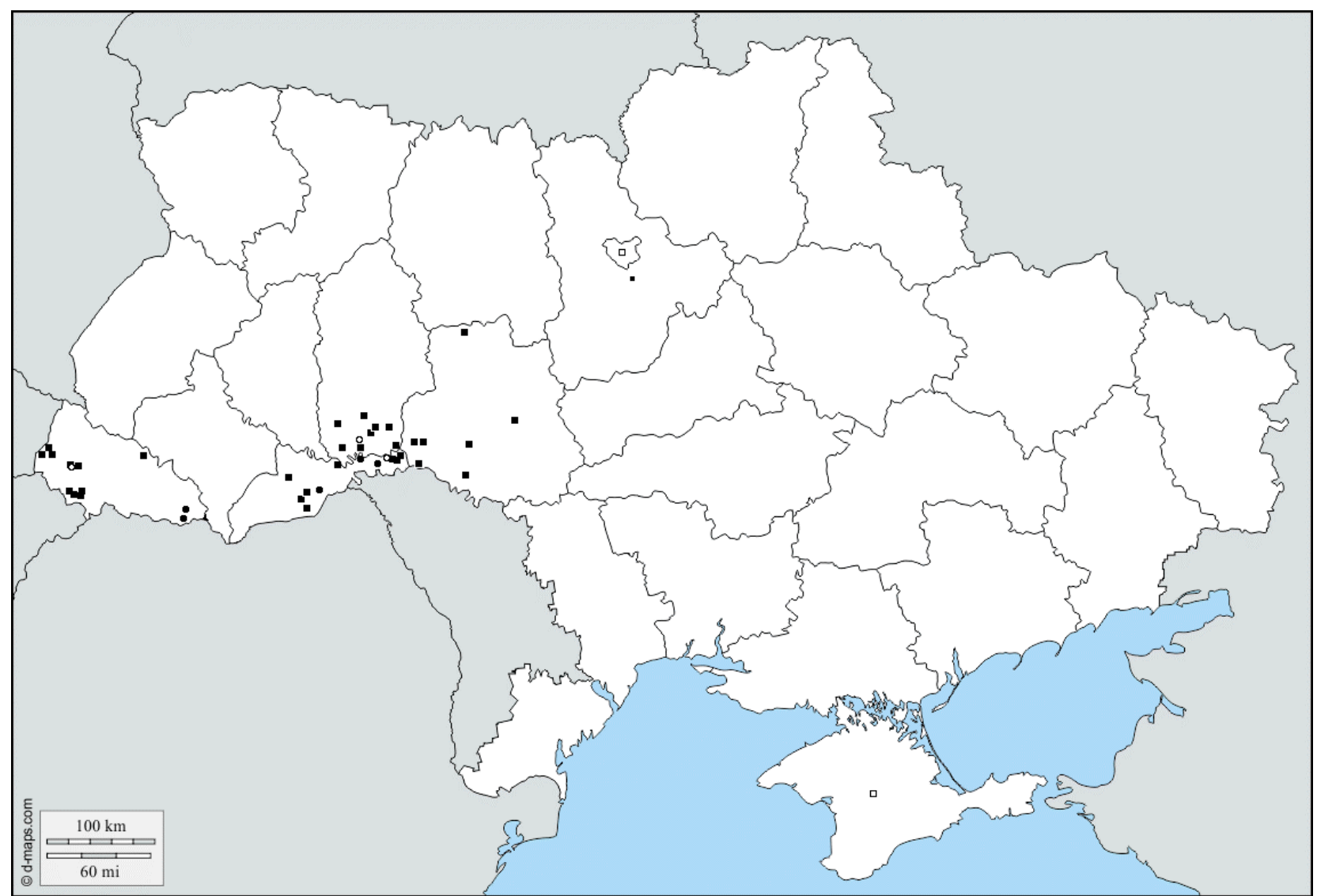

Fig.3. Distribution map of Loranthus europaeus in Ukraine. Designations: • - authors' observations during 2005-2019; $\circ-$ observations from personal communications; - - data from the literature and herbarium specimens; $\square-$ unconfirmed data

within the European range of L. europaeus (Cramp, Perrins, 1994).

Patterns of distribution of Loranthus europaeus in

\section{Ukraine}

In the continental part of Ukraine L. europaeus occurs at the northeastern boarder of its range in Eastern Europe mostly in natural oak forests in Western and Central-Western Ukraine (Fig. 3). As compared to the continental climate of the most of Ukraine, in southwestern part it is milder, with snowy winters and average temperatures below freezing and higher precipitation during warm season (Peel et al., 2007).

List of localities:

Chernivtsi Region. Hertsayivs'ky District: near Kulykivka village, silviculture, on Quercus rubra, 14.09.2013, 09.06.2014, O. Volutsa (CHER!); near Kulykivka village, on $Q$. rubra and $Q$. robur, 08.11.18, O. Volutsa (CHER!); Hlybots'kyi District: "Im Walde bei Terescheni auf Eichen" [in forest near Tarashany on oaks] (Herbich, 1853); "In Walde zwischen Tarescheny und Oprischeny parasitisch auf Eichen" [in forest between Tarashany and Oprisheny parasites on oaks] (Herbich, 1859); Dubivtsi (Herbich) [now Oprisheny] (Bordzilovskyi, Lonachevskyi, 1952); Oprișeni, Prevoroche [Oprysheny and Pryvoroky villages] (TTopa, 1936); between Tarashany and Valya Kuzmina villages, oak-beech forest along the old route, on $Q$. robur, 09.03.19, O. Volutsa, K. Korzhan (CHER!); [Note: this locality should be considered as one site, since this population parasitized hosts in the same forest, along which are the villages mentioned above are located. Moreover, this population, observed by us in 2019, might be the one recorded by Herbich in 1853 and 1859); Kelmenets'ky District: near Hrushivtsi village, Kelmenetske forestry, on Q. petraea, 21.05.2005, O. Volutsa, A. Tokaryuk, T. Nykyrsa T. (CHER!) [now Khotyns'ky National Park]; Ivanivtsi village, CarpinusQuercus forest, on Q. robur, 18.11.2018, O. Volutsa (CHER!); Sokyrians'ky District: Lomacin-Pietrosul 
[Lomachyntsi village], 29.04.1935, E. Tsopa (CHER!); "Pietrosul" Lomaceneț jud. Hotin (T,opa, 1936); slopes of the Dnister Reservoir near Lomachyntsi village, 10.06.1985, [I. Kh.] Udra (KW009260!); Khotyns'ky National Park, forest near Korman' village, 15.04.2012, D. Svyrydiuk $\left(48^{\circ} 34^{\prime} 9.22^{\prime \prime} \mathrm{N} 27^{\circ} 10^{\prime} 33.01^{\prime \prime}\right.$ E, pers. comm.); Khotyns'ky National Park, between Kulyshivka and Korman villages, Romankivets'ke forestry, oak forest on the slope of the Dnister River, parasitic on $Q$. petraea, 11.08.2014, V. Budzhak, I. Chorney, A. Tokaryuk (CHER!).

Zakarpattia Region. Berehivs'ky District: Berehy village, in oak forest on $Q$. robur, 19.05.1947, [?] Sladkevich, (KWHA!); in oak forest near Kvasove village, parasitizing Q. robur, 17.06.1948, F. Gryn (KW!); Kvasove (F. Gryn) (Bordzilovskyi, Lonachevskyi, 1952); near Berehove and Velyka Bakchta, [05.06.1951], I. Sydorenko, S. Fodor (UU); Berehove, in forest Atak (F. Gryn) (Bordzilovskyi, Lonachevskyi, 1952); Volcanic Carpathians, Golden Mountain in Berehove city environs, SE slope, 16.08.1965, V. I. Chopyk (KW!); near Dobrosillya $(=$ Bene) village, above the Borzhava River, 24.07.1985, I. Kh. Udra (KW!); Mukachevs'kyi District: near Verchniy Koropets village, 20.05.1952, I. Sydorenko (UU, image); Muckachevo city environs, near monastery, 06.09.1972, O. M. Dubovyk (KW!); near Mukachevo city, Lovachka Mt., (48 27'34.7" N $22^{\circ} 42^{\prime} 00.7^{\prime \prime}$ E), 11.07.2018. V. Loya (UU, pers. comm.); Rakhivs'kyi District: oak forests, suburbs of Velykyy Bychkiv, Transcarpathia, 06.02.2016, R. Gleb (pers. comm., image); oak forests of $Q$. robur and $Q$. petraea, Svydovets Ridges, 500-600 m a.s.1. (47 $58^{\prime} 28.32^{\prime \prime} \mathrm{N}$ $24^{\circ} 2^{\prime} 21.42^{\prime \prime}$ E), 05.11.2018, R. Gleb (pers. comm., image); Uzhhorods'kyi District: near Onokyvtsi village

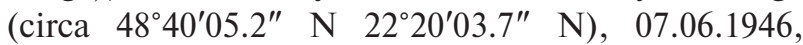
[?] Pavlova, ID 058614 (LW, image); near Onokyvtsi village, $Q$. sessiliflora $(Q$. petraea) forest, 07.06.1946, [?] Pavlova (KW!); Onokivtsi village environs, 11.09.1950, S. Fodor (UU, image); Onokyvtsi (Pavlova) (Bordzilovskyi, Lonachevskyi, 1952); Uzhhorod city, oak forest, 15.06.1951, I. Sydorenko, S. Fodor (UU, image); near Kholmets' (Helmech) village, 28.06.1956. [?] Iliganets', S. Fodor (UU, image).

Khmelnyts'kyi Region. Quercus-Carpinus forest, natural and planted $Q$. petraea oak forests, Podils'ky Tovtry National Nature Park (Novosad, Krytska, Lyubinska, 2009). Chemerovets'kyi District: Cherche village, Sadova Tovtra, 23.07.1963, 18.10.1967, 10.09.1968, I.I. Moroz (KWHA!); Dunaivtsi District (Lyubinska, Yuhlichek, 2017): Gorchychna (Lapchynskyi) [now
Girchychna]; Syvorogy (Makovetskyi) (Bordzilovskyi, Lonachevskyi, 1952); between Syvorohy and Kuzhelevo villages (Schmalhausen) (Schmalhausen, 1886; Bordzilovskyi, Lonachevskyi, 1952); Minkovtsy [?] Podolie [?] de Nouo-Vuschitsa dans le bois [in the forest] de Kovtonne sur un vieux chêne [on old oak tree], pl[ante] parasite, pl[ante] rare, 14.08.1881, [V.V.] Montresor (KW!) [between Mynkivtsi village and Nova Ushitsya]; (Schmalhausen, 1886; Bordzilovskyi, Lonachevskyi, 1952); on old oak trees near Minkovtsy and Otrokova villages (Montresor, 1886); near Nova Ushitsya by postal road to Yampil (Montresor, 1886); Minkovets'ke forestry, on oaks, 25.06.1985, [I. Kh.] Udra (KW! KW 009259); Kamianets-Podils'kyi District (Lyubinska, Yuhlichek, 2017): between Demshyn and Kytayhorod villages near mouth of the Ternava River (Makovetskyi) (Bordzilovskyi, Lonachevskyi, 1952); near Nygyn village, on oaks, at Tovry, 22.07.1935, O1. Sokolovsky, V. Schidlovsky (KWHU!); "Cykivs'ky" landscape protected area (Kovalchuk, 2017); Podils'ky Tovtry National Nature Park, near Vyhvatnivtsi village, 25.01.2018. D. Svyrydiuk, pers. comm. $\left(48^{\circ} 40^{\prime} 05.2^{\prime \prime} \mathrm{N}\right.$ 26 51'47.0" E); Novoushitsky District: slopes of the Dnister Reservoir near Rudkovtsy village [0]6.06.1985, [I. Kh.] Udra (KW! KW009258).

Vinnytsya Region. Haysynskyi, Lypovetskyi, Bratslavskyi Districts (Balkovsky) (Bordzilovskyi, Lonachevskyi, 1952); Mohyliv-Podilskyi (Vilchynskyi) (Bordzilovskyi, Lonachevskyi, 1952); Murovanokurylivets'ky District: Vyscheolchadayiv village, VyscheOlchadayivska sugarmill, at oaks at the edge of a forest, Mohylivs'ka Ring Road, 30.09.1926, N.O. Verner, M. Bilozor (KW!); Nemyrivs'kyi District, Bratslav city, "...distributed exclusively....in our forests..." (Zhuravl, 1929); Sharhorodsky District: Kropyvna (Rogowitsch) (Bordzilovskyi, Lonachevskyi, 1952); Derebchyn (Vilchynsky) (Bordzilovskyi, Lonachevskyi, 1952); Yampil's'kyi District: Bezvodne village, 21.06.1969, D.S. Ivashin, I.I. Moroz (KWHA!).

Kyiv Region. Kagarlyts'ky District: Lipovets village. "3361. Kiew, pr. Lipowez", 10.08.1857, Rogowitsch [Rogovich]. Herb. Ed. Lindemann (MSUD, image); "Kyiv Lipovetsky uyezd near Zabory farm in Ometyn'skyi forest" [Киев. Липов. у. около хутора Заборы в Ометинском лес] (Schmalhausen, 1886).

Kyiv Region (unconfirmed). Kyiv environs, "...very rare...on Quercus robur L. branches..." (Stankov, Taliyev, 1949; Atlas Florae Europaeae, 1976).

Crimea (unconfirmed). "...on Fagaceae..." (Beylin, 1986; Morozyuk, 1987; Golubev, 1996). 
According to Fodor (1974), this hemiparasitic species resides mainly in the Transcarpathian Lowland, Foothills and the lower forest belt. Probably localities in Ukraine are in the northeastern border of the range of L. europaeus in Europe, and its distribution is limited by climatic factors.

Zawadzki in his Enumeratio plantarum Galiciae et Bucowinae (Zawadski, 1835) reported L. europaeus as parazitizing oaks near Lviv ("Auf Eichen um Lemberg"), though this record has not been confirmed later (Bordzilovskyi, Lonachevskyi, 1952), or probably the species has already disappeared in that locality. Thus, the first reliable and confirmed record of $L$. europaeus in Ukraine was published by Herbich in his Stirpes rariores Bucovinae... (Herbich, 1853), where the species was reported "Im Walde bei Terescheni auf Eichen" (Hlybots'kyi District, Chernivtsi Region). In his later overview of the flora of Bukovina, Herbich (1859) confirmed the locality of L. europaeus mentioned in his previous publication: "Im Walde zwischen Terescheny und Oprischeny parasitisch auf Eichen". Moreover, in his book on plants of Galicia (Galychyna) and Bukovina Ueber die Verbreitung in Galizien und der Bukowina wildwachsenden Pflanzen Herbich (1861) summarized the data on plant species composition in this region, referring to his earlier works as well as to works of other botanists, including the publication of Zavadsky, who reported L. europaeus from Lviv (see above).

In turn, the first known records of $L$. europaeus in Ukraine were reported by V.V. Montresor, who collected it on 14 August, 1881 in Podillya (Latinized as Podolia) near Nova Ushytsya (see the cited specimen above). Montresor (1886: 59) reported Loranthus europaeus only for the current Khmelnyts'kyi Region as "Growing on old oaks near Mynkovets and Otrokova villages of Nova Ushitsya county (иyezd - уезд); near Nova Ushitsya by a postal road to Yampil city. August. Flowers yellow-greenish, fruits yellowish. The plant is parasitic [the archaic word "чужеядное" was used in the original Russian text], rarely occurring" (translated from Russian: Montresor, 1886). It is noteworthy that the hemiparasite persisted in the same area for more than 100 years, since it was recorded there also in 1985. In Murovanokurylivets'ky District, at VyscheOlchadayivska sugar mill of Vyscheolchadayiv village, L. europaeus parasitized oaks at the edge of a forest near Mohylivs'ka ring road, what was observed on 30 September 1926 by N.O. Verner and M. Bilozor. The easternmost confirmed locality of L. europaeus in Ukraine and in Eastern Europe in general is in a "pure" (monodominant) oak forest near Bezvodne village (Vinnytsya Region, Yampils'kyi District), where the species was found on 21 June 1969.

Schmalhausen (1886) provided general data on the range of L. europaeus and some localities in Kyiv and Khmelnyts'kyi regions: on oaks, rarely, Lipovetsky uyezd near Zabory farm in Ometyn'skyi forest near Novoushytskyi uyezd between Syvoroha and Kuzhelivka villages, Minkovtsy - in Koltun forest (Montresor!) [На дубах; редко. Киев. Липов. у. около хутора Заборы в Ометинском лесу под. Новоуш. у. между дд. Сиворога и Кужелевка! Миньковцы - в лесу Колтун (Монтрезор!)].

The early collections of $L$. europaeus in the western part of Ukraine were done by the Romanian botanist Emilian Tsopa (Topa) in 1935 from the environs of Lomachyntsi village (Sokyrians'ky District, Chernivtsi Region); he reported it as a supposedly new species for the regional flora [of North Basarabia] (T,opa, 1936). This locality was also recorded by Udra in 1985. Loranthus europaeus from Chernivtsi Region is also known from the Prut-Dnister interfluvial area (Prut-Dnistrovske Mezhyrichchya) in Kelmenets'ky and Sokyrians'ky districts and in Bukovynian CisCarpathia (Bukovyns'ke Prykarpattia) in Hertsayivs'ky and Hlybots'ky districts. Only 70 years after that record, a new locality of $L$. europaeus parasitizing $Q$. petraea was revealed near Hrushivtsi village (Kelmenets'ky District) in 2005 (Volutsa, Nykyrsa, Tokaryuk, CHER), then in 2012 by D. Svirydiuk near Korman' village, in 2013 in Kulykivka village (Hertsayivs'ky District) (Volutsa, CHER), and in 2014 - between Kulyshivka and Korman' villages (Sokiryans'ky District) (Budzhak, Chorney, Tokaryuk, CHER).

One of the largest surveyed populations of L. europaeus in Chernivtsi Oblast was revealed recently near Kulykivka village (Hertsayivs'ky District). The total area of parasitized 15-25 m-high stands of Quercus rubra was ca. $600 \mathrm{~m}^{2}\left(150 \times 50 \mathrm{~m}^{2}\right)$ located at the northern slopes (30-40 steepness). Besides $Q$. rubra, the forest comprised other trees and shrubs, such as $Q$. robur, Carpinus betulus, Acer platanoides L., Fagus sylvatica L., Populus tremula L., and Cerasus avium (L.) Moench (Prunus avium (L.) L.). It should be noted that one of exophytes of L. europaeus was $1.5-2$ $\mathrm{m}$ in diameter, and many residual parasitic stems on the swollen host branches were revealed. However, only one parasitized tree of $Q$. robur with a low rate of infestation by L. europaeus was found in this locality, as compared with $Q$. rubra; though, at the plain part of that hill three 
more trees of $Q$. robur resided at the edge of a mixed Quercus-Fagus forest, having several $L$. europaeus exophytes on the upper thirds of trees. Thus, a tree 18 $\mathrm{m}$ tall and $30 \mathrm{~cm}$ in diameter had three yellow mistletoe exophytes, while the other two trees, being 15-18 m tall and $25-28 \mathrm{~cm}$ in diameter, had only one exophyte each.

A new site was revealed recently near Ivanivtsi village (Kelmenets'ky District, Chernivtsi Region) on 18 November 2018, where L. europaeus parasitized Q. robur trees $(25-30-\mathrm{m}$ tall and $50-100 \mathrm{~cm}$ in diameter) forming the first layer of a Carpinus - Quercus forest with the admixture of young Carpinus trees at the second one located at the comparatively flat top of the hill at the outskirts of the village towards Sokyryans'ky District. This population of L. europaeus occupied ca. 5 ha $\left(100 \times 500 \mathrm{~m}^{2}\right)$ of the forest with the central part with small growing trees lacking the parasite due to recent cuttings. Some exophytes reached $50-80 \mathrm{~cm}$ in diameter, and, additionally, had abundant maturating berries. The relative density of the infected trees was ca. one plant per $25-50 \mathrm{~m}^{2}$. Regarding the relatively rare occurrence of L. europaeus in Ukraine, and its residence at the northeastern boarders of the Eastern European part of the species range, this hemiparasitic species is recommended to be protected at regional level in Chernivtsi Region.

It is noteworthy that L. europaeus has been already included to the list of rare, relict and endemic species of the Eastern Podillya Region, namely, at the Cykivs'ky landscape protected area, Khmelnyts'kyi Region (Lyubinska, Yuhlichek, 2017). In turn, the yellow dwarf mistletoe was revealed at Kamianets-Podil's'ky Region on oaks near Nygyn village, at Tovtry by Ol. Sokolovsky and V. Schidlovsky on 22.07.1935, also nearby, in a Quercus-Carpinus forest, natural and planted Q. petraea oak forests in Podils'ky Tovtry National Nature Park (Novosad et al., 2009), and recently, on 25 January 2018, by D. Svyrydiuk, in the same national park. In Chemerovets'kyi District, near Cherche village this hemiparasitic species parasitizing $Q$. robur was recorded several times (23 July 1963, 18 October 1967, 10 September 1968). In Novoushitsky District I. Udra collected L. europaeus at slopes of the Dnister Reservoir near Rudkovtsy village on 6 June and 25 June 1985.

In the Carpathians Mountains, two adjacent L. europaeus populations were recorded by R. Gleb on 11 May 2018 in the oak forests $\left(50 \times 25 \mathrm{~m}^{2}\right)$ comprised of $Q$. robur and $Q$. petraea located at one of ridges of the Svydovets' (near Velykyi Bychkiv village, Rakhivs'kyi district) at altitudes of $500-600 \mathrm{~m}$ a. s. 1 . Circa $30 \%$ of old $Q$. robur and $Q$. petraea trees on western slopes (steepness $10-20^{\circ}$ ) were parasitized mostly in the upper part of trees, ca. 5-10 aerial shoots per a host tree. It is noteworthy that most of old oaks survived cuttings. At the edge of a Fagus-Quercus deciduous forest, two infected trees of $Q$. robur located at some distance from each other were revealed on the western slope (steepness $5^{\circ}$ ). Six heavily infected $Q$. robur trees bearing 8-12 aerial shoots of L. europaeus at upper part of the crowns were found by the edge of a $90 \mathrm{~m}$-long and 10-15 m-wide woodland belt on a northwestern slope (steepness $5^{\circ}$ ). Moreover, at the eastern slope (steepness $5-10^{\circ}$ ) at the edge of the oak forest, one $Q$. robur tree was parasitized by 5-10 L. europaeus individuals. In turn, on the western slope (steepness $5^{\circ}$ ) 8-10 hemiparasites were recorded on the upper part of $Q$. robur and $Q$. petraea tree crowns ( 8 trees in total). Furthermore, the largest $L$. europaeus samples (more than $50 \mathrm{~cm}$ in diameter), 8-12 individuals per a host tree, were observed on four $Q$. robur trees growing at the edge of Fagus-Quercus forest on western slope (steepness $5^{\circ}$ ).

In the Carpathian Biosphere Reserve, Chorna Hora Botanical Reserve (Vynohradivs'kyy district, near Vynohradiv city), L. europaeus was recorded in Q. robur and $Q$. petraea oak forests mixed with Fagus by R. Gleb on 25 February 2016. This population of the parasite resided at northern slopes (steepness $5-25^{\circ}$ ) at $230 \mathrm{~m}$ a.s.1., and circa $30 \%$ of the hosts were bearing L. europaeus aerial shoots. It is worth mentioning that approximately $50 \%$ of oaks were concomitantly infected by a transverse cancer accompanied by the massive wilting of oak trees in this locality.

The hemiparasite was also recorded at Mukachevo city environs, near the monastery, on 6 September 1972 by O.M. Dubovyk. Several individuals of a yellow mistletoe parasitized solitude $Q$. robur growing at the side of road H09 (Muckachevo-Rohatyn) in Zaluzhzhya village environs (Zakarpattia Region, Muckachevs'ky district) on 13 November 2018. It was collected by I. I. Moroz also at Berehivs'ky District at Berehy village, on 9 May 1947, on Q. robur by F. Gryn in an oak forest near Kvasove village on 17 June 1948, and by I. Sydorenko and S. Fodor in Berehove and Velyka Bakchta environs on 5 June 1951. The species occurs also in Volcanic Carpathians, namely at southeastern slopes of the Golden Mountain near Berehove city, where it was recorded at 16 August 1965 by V. I. Chopyk, and later, on 24 July 1985 at Dobrosillya $(=$ Bene) village environs above the Borzhava River, 24 July 1985, found by I.Kh. Udra. 


\section{Unconfirmed and/or erroneous records}

Loranthus europaeus from Vinnytsya Region (Nemyrivskyi District, Bratslav city) was mentioned in the Flora of Tultsyinshyna by Zhuravl (1929); however, no herbarium specimens were found. In Kyiv Region, the species was recorded on 10 August 1857 by A.S. [P.S.] Rogovych [Rogowicz] in Kagarlyts'ky District, Lipovets village, and the corresponding specimen is deposited at MSUD (personal collection of E.E. Lindemann), mentioned by Stankov and Taliev (1949) and later in the Atlas Florae Europaeae (1976): "...on Quercus robur branches - very rare, recorded for Kyiv environs. Hemi-parasite". Finally, the most challenging task still remains to confirm the observations from the Crimean Peninsula on Fagaceae mentioned by Morozyuk (1987) and Golubev (1996).

Generally, our data indicate that native (autochthonous) deciduous species of oaks are primary hosts for L. europaeus in Ukraine. Forty years ago the area of oak forests in Ukraine embraced $26 \%$ of the total forest cover in Ukraine (Shelyag-Sosonko, 1974), but now they declined due to several anthropic and natural factors. Species of Quercus often host both L. europaeus and Viscum album L. in the western regions of the country.

It is evident that this mistletoe species is not expected to become a noxious pest causing considerable damage to the Ukrainian forests, unlike Viscum album. Moreover, in Khmelnyts'kyi Region L. europaeus is even included in the list of regionally rare species (Kovalchuk, 2017). Following the Second Addendum to the Decision of the $5^{\text {th }}$ Session of the Council of Khmelnyts'kyi Region (Oblastna Rada) of 20 December 2006, No. 18$5 / 2006$, L. europaeus is present in the "List of species recommended for special protection in Khmelnyts'kyi Region" (see Andriyenko, Peregrym, 2012).

\section{Conclusions}

The geographic distribution range of the aerial hemiparasitic plant species Loranthus europaeus in Ukraine is confined to the southwestern regions of the country. In total, this species was reported from ca. 30 localities in Ukraine, though the records from Kyiv Region and Crimea remain unconfirmed. Loranthus europaeus parasitizes Quercus species as its primary hosts within its range in Ukraine. Due to its hemiparasitic nature and limited distribution, L. europaeus is not expected to become a noxious pest; on the contrary, it is recommended to be protected in Ukraine at the regional level.

\section{Acknowledgments}

The authors appreciate the kind help of curators and research staff of the Ukrainian herbaria: Natalia Shiyan (KW); Olexander Shynder (KWHA); Marychka Romaniv (LW); Olena Bondarenko and Tetyana Vasylyeva (MSUD), Andriy Yena (CSAU), as well as Myroslav Shevera (M.G. Kholodny Institute of Botany, National Academy of Sciences of Ukraine, Kyiv), who analyzed specimens from UU and UHM. The National Academy of Sciences of Ukraine is acknowledged for the research grant for young scientists (Agreement \# 52/18A of 16 October 2018). We thank Kateřina Janošikova (scientific illustrator, Centre for Science Communication, Palacký University in Olomouc, Olomouc, Czech Republic) for illustrations (Fig. 1), and Vlasta Loya (M.M. Gryshko National Botanical Garden, Kyiv, Ukraine), Karol Rydlo (Zall Letov Simulátory, Olomouc, Czech Republic), Dmytro Svyrydiuk (Podilski Tovtry National Nature Park, Ukraine), and Mykyta Peregrym (Eszterházy Károly Egeyten, Eger, Hungary) for digital images of L. europaeus. Microscopy images (Fig. 2, I-R) were obtained using AXIO ZOOM 16 (Carl Zeiss, Germany) light microscope in the Centre of the Region Haná for Biotechnological and Agricultural Research, Faculty of Science, Palacký University (Olomouc, Czech Republic). We are grateful to Prof. Sergei L. Mosyakin (M.G. Kholodny Institute of Botany, National Academy of Sciences of Ukraine, Kyiv) for his valuable taxonomic suggestions, various corrections, and editorial improvement of the language of the manuscript.

\section{REFERENCES}

Andriyenko T.L., Peregrym M.M. 2012. An official list of regionally rare plants of the administrative territories of Ukraine. Kyiv: Alterpress, 146 рр. [Андрієнко Т.Л., Перегрим М.М. 2012. Офіційні переліки регіонально рідкісних рослин адміністративних територій України. Київ: Альтерпрес, 146 с.]. Available at: http://www. botany.kiev.ua/doc/of_reg_sp.pdf

Atlas Florae Europaeae. 1976. Distribution of vascular plants in Europe: Salicaceae to Balanophoraceae, vol. 3. Eds J. Jalas, J. Suominen, Helsinki, 128 pp.

Aukema J.E. 2003. Vectors, viscin, and Viscaceae: mistletoes as parasites, mutualists, and resources. Frontiers in Ecology and the Environment, 1(4): 212-219.

Bordzilovskyi Ye.I., Lonachevskyi O.O., 1952. Loranthaceae. In: Flora URSR, vol. 4. Ed. M.I. Kotov. Kyiv: Vydavnytstvo AN Ukrainskoi RSR, pp . 170-176. [Бордзіловський Є.I., Лоначевський О.О. 1952. Loranthaceae. Флора УРСР, т. 4. Ред. М.І. Котов. Київ: Видавництво АН Української РСР, с. 170-176.]

Beylin Y.H. 1986. Parasitism and epiphytotiology (on an example of parasitic angiosperms), Moscow: Nauka, 352 рр. [Бейлин И.Г. 1986. Паразитизм и эпифитотиология (на примере паразитов высших растений). Москва: Наука, 352 с.]

Chopyk V.I., Bortnyak M.M., Pogrebennyk V.P., Kucheryava L.F., Nechytaylo V.A., Lubchenko V.M., Schvtsyk V.L. 1998. Konspekt flory Serednoho 
Prydniprov'ya. Sudynni roslyny, Kyiv: Phytosociocenter, 140 pр. [Чопик В.І., Бортняк М.М., Войтюк Ю.О., Погребенник В.П., Кучерява Л.Ф., Нечитайло В.А., Любченко В.М., Шевчик В.Л. 1998. Конспект флори Середнього Придніпров'я. Судинні рослини, Київ: Фітосоціоцентр, 140 с.]

Cramp S., Perrins C.M. 1994. The birds of the Western Palearctic. Crows to finches. In: Handbook of the birds of Europe, the Middle East, and North Africa. vol. 8, United Kingdom: Oxford University Press, 956 pp.

Eliás P. 1985. K výskytu imelovcovitých (Loranthaceae) na Slovensku. Zprávy České botanické společnosti, 20: $128-132$.

Fodor S.S. 1974. Flora of Transcarpathia. Lviv: Vyshcha shkola, 208 pp. [Фодор С.С. Флора Закарпаття. 1974. Львів: Вища школа, 208 с.].

Glatzel G. 1983. Mineral nutrition and water relations of hemiparasitic mistletoes: a question of partitioning. Experiments with Loranthus europaeus on Quercus petrae and Quercus robur. Oecologia, 56 (2-3): 193-201. https://doi.org/10.1007/BF00379691

Glatzel G., Geils B.W. 2008. Mistletoe ecophysiology: host-parasite interactions. Botany, 87(1): $10-15$.

Glatzel G., Richter H., Devkota M.P., Amico G., Lee S., Lin R., Grabner M., Barlow B.A. 2016. Foliar habit in mistletoe-host associations. Botany, 95(3): 219-229. http://dx.doi.org/10.1139/cjb-2016-0238

Golubev V. N. 1996. Biological flora of the Crimea. Yalta, Nikitsky Bot. Garden. 126 pp. [Голубев В. Н. 1996. Биологическая флора Крыма. Ялта: НБС-ННЦ, 126 с.].

Grazi V. G., Urech K. 1985. Hyperparasitismus von Viscum album auf Loranthus europeaeus als mögliches Bekämpfungsmittel gegen die Eichenmistelplage. Beitrage zur Biologie der Pflanzen, 60: 467-474.

Grímsson F., Grimm G. W., Zetter R. 2018. Evolution of pollen morphology in Loranthaceae. Grana, 57(1-2): 16-116. http://dx.doi.org/10.1080/00173134.2016.1261 939

Herbaria of Ukraine. Index Herbariorum Ucrainicum. 2011. Ed. N.M. Shiyan. Kyiv: Alterpress, 442 pp. [Гербарii України. Index Herbariorum Ucrainicum. 2011. Ред.-укл. Н.М. Шиян. Київ: Альтерпрес, с. 442].

Herbich F. 1853. Stirpes rariores Bucovinae, oder die seltenen Pflanzen der Bucovina. Stanislawow: Gedruckt bei Johann Paul Piller, 65 pp.

Herbich F. 1859. Flora der Bukowina. Leipzig: Verlag von V. Folckmar, vi +460 pp.

Herbich F. 1861. Ueber die Verbreitung in Galizien und der Bukowina wildwachsenden Pflanzen. Verhandlungen der Kaiserlich-Königlichen Zoologisch-Botanischen Gesellschaft in Wien: 33-70.

Kogelnik M. 2002. Ohmeljevke (Loranthaceae) in omelovke (Viscaceae) v Sloveniji. Diplomsko delo. Univerza v Ljubljani, Biotehniška fakulteta, Oddelek za biologijo, 130 pp.

Krüssmann G. 1977. Handbuch der Laubgehölze. Band II. Berlin und Hamburg: Verlag Paul Parey, 66 pp.

Kubát K. 1997. Loranthaceae. In: Květena České republiky. vol. 5, Ed. B. Slavík. Praha: Academia, pp. 467-468.
Kuijt J. 2015. Santalales. In: The Families and Genera of Vascular Plants, vol. 12. Ed. K. Kubitzki. Heidelberg; New York; Dordrecht; London: Springer, pp. 2-189. https://doi.org/10.1007/978-3-319-09296-6

Kumbasli M., Keten A., Beskardes V., Makineci E., Özdemir E., Yilmaz E., Zengin H., Sevgi O., Yilmaz H.C., Caliskan S. 2011. Hosts and distribution of yellow mistletoe (Loranthus europaeus Jacq. (Loranthaceae)) on Northern Strandjas Oak Forests-Turkey. Scientific Research and Essays, 6(14): 2970-2975. https://doi. org/10.5897/SRE10.1178

Lyubinska L.H., Yuhlichek L.S. 2017. Flora Khmelnychchyny. Khmelnytskyi: Polihrafist, 240 pp. [Любінська Л.Г., Юглічек Л.С. 2017. Флора Хмельниччини. Хмельницький: Поліграфіст, 240 с.].

Margl H.D., Mayer H. 1981. Waldbauliche Untersuchungen über den Befall der Eichen durch die Eichenmistel (Loranthus europaeus) im Weinviertel, Wien. Allgemeine Forstzeitung, 92(5): 178-180.

Marynych O., Parkhomenko H., Petrenko O., Shyshchenko P. 2003. Improved scheme of physical-geographical classification of districts of Ukraine. Ukrainian Geographical Journal, 1: 16-21. [Маринич O.М., Пархоменко Г.О., Петренко О.М., Шищенко П.Г. 2003. Удосконалена схема фізико-географічного районування України. Український географічний журнал, 1: 16-21].

Mathiasen R.L., Nickrent D.L., Shaw D.C., Watson D.M. 2008. Mistletoes: pathology, systematics, ecology, and management. Plant Disease, 92(7): 988-1006. https:// doi.org/10.1094/PDIS-92-7-0988

Matula R., Svátek M., Pálková M., Volařŕk D., Vrška T. 2015. Mistletoe infection in an oak forest is influenced by competition and host size. PloS One, 10(5): p.e0127055. https://doi.org/10.1371/journal.pone.0127055

Montresor V.V. 1886. Obozrenye rasteniy, vkhodyashchikh v sostav flory guberniy Kievskogo uchebnogo okruga: Kievskoy, Podolskoy, Volynskoy, Chernigovskoy i Poltavskoy. Zapiski Kievskogo obshchestva estestvoispytateley, 8(1): 59. [Монтрезор В.В. 1886. Обозрение растений, входящих в состав флоры губерний Киевского учебного округа: Киевской, Подольской, Волынской, Черниговской и Полтавской [Часть 1]. Записки Киевского общества естествоиспытателей, 8(1): 1-144].

Morozyuk S.S. 1987. Loranthaceae. In: Opredelitel vysshikh rasteniy Ukrainy. Ed. Yu.N. Prokudin et al. Kiev: Naukova Dumka, pp. 242-243. [Морозюк C.C. 1987. Loranthaceae. Определитель высших растений Украины. Ред. Прокудин Ю.Н. и др., Киев: Наукова думка, с. 242-243].

Nickrent D.L., Malécot V., Vidal-Russell R., Der J.P. 2010. A revised classification of Santalales. Taxon 59(2): 538-558.

Novosad V.V., Krytska L.I., Lyubinska L.G. 2009. Fitobiota natsionalnogo pryrodnogo parku "Podilski Tovtry". Sudynni roslyny. Kyiv: Fiton. 292 pр. [Новосад В.В., Крицька Л.І., Любінська Л.Г. 2009. Фітобіота національного природного парку "Подільські Товтри". Судинні рослини. Київ: Фітон, 292 с.] 
Peel M.C., Finlayson B.L., McMahon T.A. 2007. Updated world map of the Köppen-Geiger climate classification. Hydrology and Earth System Sciences Discussions, 4(2): 439-473. https://doi. org/10.1127/0941-2948/2006/0130

Saraj B.S., Kiadaliri H., Akhavan R., Kafaki S.B. 2015. Spatial variation and dispersion pattern of European yellow mistletoe (Loranthus europaeus) affected forests in Zagros area, a case study of Ilam forests. Iranian Journal of Forest and Range Protection Research, 12(2): Pe94Pe106 ref.35

Schmalhausen I.F. 1886. Flora of South-Western Russia, or Governorates of Kiev, Volhynia, Podolia, Poltava, Chernigov, and adjacent territories. Kiev: O.V. Kulzhenko Publ., xlviii + 783 pp. [Шмальгаузен И.Ф. 1886. Флора Юго-Западной России, т.е. губерний: Киевской, Волынской, Подольской, Полтавской, Черниговской и смежных местностей. Киев: О.В. Кульженко, xlviii + 783 pp.].

Shavvon R.S., Mehrvarz S.S., Golmohammadi N. 2012. Evidence from micromorphology and gross morphology of the genus Loranthus (Loranthaceae) in Iran. Turkish Journal of Botany, 36: 655-666.

Shelyag-Sosonko Yu.R. 1974. The forests of common oak formation at Ukraine and their evolution. Kyiv, Naukova Dumka, 240 pр. [Шеляг-Сосонко Ю.Р. 1974. Ліси формації дуба звичайного на території України та їх еволюція. Київ: Наук. думка, 240 с.].

Stankov S.S., Taliev V.I. 1949. Identification manual of higher plants of the European part of the USSR. Moscow: Sovetskaya Nauka, 1152 pp. [Станков C.С., Талиев В.И. 1949. Определитель высших растений Европейской части СССР. Москва: Советская наука, 1152 с.].

Thiers B. 2008-onward. Index Herbariorum. A Global Directory of Public Herbaria and Associated Staff. New York Botanical Garden's Virtual Herbarium. Available at: http://sweetgum.nybg.org/ih/ (Accessed 8 November 2018).
Țopa E. 1936. Fragmente floristice din Bucovina şi Basarabia de Nord. Buletinul Grădinii Botanice şi al Muzeului Botanic dela Universitatea din Cluj, 1-4: 209-218.

Tübeuf K.F. von. 1923. Monographie der Mistel. München; Berlin: R. Oldenbourg, xii + 832 pp. https://doi. org/10.5962/bhl.title. 15456

Uotila P. 2011-onward. Loranthaceae. In: Euro+Med Plantbase - the information resource for EuroMediterranean plant diversity. Available at: http://ww2. bgbm.org/EuroPlusMed/PTaxonDetail.asp?NameId=2 $5267 \&$ PTRefFk $=7300000$

Watson D.M. 2001. Mistletoe - a keystone resource in forests and woodlands worldwide. Annual Review of Ecology and Systematics, 32 (1): 219-249. https://doi. org./10/1146/annurev.ecolsys.32.081501.114024

Yena A.V. 2012. Spontaneous flora of the Crimean Peninsula. Simferopol: N. Orianda. 232 pp. [Ена A.В. 2012. Природная флора Крымского полуострова. Симферополь: Н. Оріанда, 232 с.].

Zawadski A. 1835. Enumeratio plantarum Galiciae \& Bucowinae, oder die in Galizien und der Bukowina wildwachsenden Pflanzen mit genauer Angabe ihrer Standorte. Breslau: W.G. Korn, xxiv + 200 pp.

Zebec M., Idžojtić M. 2006. Hosts and distribution of yellow mistletoe, Loranthus europaeus Jacq. in Croatia. Hladnikia, 2(19): 41-46.

Zervas A., Petersen G., Seberg O. 2019. Mitochondrial genome evolution in parasitic plants. BMC Evolutionary Biology, 19(87): 1-14. https://doi.org/10.1186/ s12862-019-1401-8

Zhuravl K.S. 1929. Tulchynshchyna (krayeznavchyi zbirnyk). Tsykl 1-yi. Pryroda Tulchynshchyny. Tulchyn, 35 рр. [Журавль К.С. 1929. Тульчинщина (краєзнавчий збірник). Цикл 1-ий. Природа Тульчинщини. Тульчин, $35 \mathrm{c.}]$

Recommended for publication by G.V. Boiko 